\title{
Reflecting On Academic Development: A Dialogue About A FLEXible Journey
}

\author{
Dr Chrissi Nerantzi, \\ Dr Gerasimos Chatzidamianos
}

\author{
Manchester Metropolitan University, United Kingdom
}

\begin{abstract}
Academic development has become a core element across many higher education institutions around the globe, supported by management strategic plans and educational agendas. It has been linked with job satisfaction, student retention and teaching quality. However, it is important for academic development to harness the needs and aspirations of academic staff more fully, meet these and drive innovation in learning and teaching. To address this gap, this article introduces the FLEX initiative, developed at Manchester Metropolitan University in early 2014 and offered since then. This discussion and associated reflections are timely as the FLEX initiative is currently being reviewed.. The article is based on an invited webinar offered by the authors on the $11^{\text {th }}$ of April 2018 for the Higher Education Academy/AdvanceHE and specifically for the Flexible Learning Group to share with the wider community what FLEX is and how it works. The aim is to present a reflective narrative and tell the story of the designer of FLEX and an academic from the same institution who engaged with FLEX. This reflective dialogue informs specific recommendations that can support academic developers in managing relevant programmes of study in higher education.
\end{abstract}

Keyword: Academic Development, Reflective Practice, Continuing Professional Development, Higher Education, Professional Development 


\section{Introduction}

In the United Kingdom, academic development was started in the 1970s by approximately 30 pioneers who were passionate about learning and teaching and seized the opportunities presented to develop teaching practices further (Baume \& Baume, 2013; Gibbs, 2013). Academic development focuses on the professional development of academics and other professionals who teach or support student learning. Academic development is usually located in a central unit. Its core activities involve offering teaching qualifications usually for staff internally, support to gain a professional recognition as well as informally through workshops, one-to-one support, networking, and open development activities. Academic developers also consult colleagues on curriculum development and scholarly activities around learning, teaching and research in higher education.

Since the Robbins (2013) report, researchers (e.g. Phuong, Cole, Zarestky, 2018) and increased government investment in the development of practitioners and their teaching have led progressively to the professionalisation of higher education (HE) teaching, the establishment of teaching qualifications, usually through Postgraduate Certificate in Learning and Teaching in Higher Education (PgCerts) and the opportunity to gain Higher Education Academy (HEA) fellowships aligned to the UK Professional Standards Framework (HEA, 2011). While there is evidence that suggests that PgCerts and HEA fellowships have a positive impact on practices (Parsons et al. 2012; Botham, 2017), there is a need today for academic development to become transformative (Stefani 2017) and seize the opportunities brought by digital and open pedagogies (Nerantzi, 2017). Crawford (2009) suggested that academics are indeed keen to develop their skills and often reach out to disciplinary networks and communities externally to their institution, especially after completing their teaching qualification. Nerantzi (2017) looked at such professional development activities within cross-boundary open communities of learning and cross-institutional academic development courses. The results indicated that academics find it motivational to learn and develop with individuals not just from other higher education institutions, disciplines and cultures, but also with practitioners from outside academia. The findings suggest that such interactions have a positive impact on engagement in professional development activities, reflection and renewal of ideas and their practice. However, academic development remains a relatively under-researched area of practice with many questions yet to be explored.

Further, there is evidence suggesting that critical reflection as a method of practice in academic development has been found beneficial for both the academic member of staff and their students (Sutherland 2013). Specifically, Larrivee (2000, 293) argued that "unless teachers develop the practice of critical reflection, they stay trapped in unexamined judgments, interpretations, assumptions, and expectations. Approaching teaching as a reflective practitioner involves fusing personal beliefs and values into a professional identity." However, the term 'reflective practice' in academic setting is a hard to define construct as the exact practices followed by academics across institutions vary significantly. As suggested by Kahn, Young, Grace, Pilkington, Rush $\&$ Willis (2006) this is often the by-product of the fact that reflective practice is not directly and explicitly linked with a specific epistemology, pedagogical approach, or

International Journal of Management and Applied Research, 2018, Vol. 5, No. 2 
theoretical framework. Reflecting within the boundaries of a framework could indeed be beneficial, as it would provide a solid foundation and structure that would support academics develop the skills needed for a deep, constructive, meaningful, targeted and sustained approach to learning and teaching through reflection. Academics, in effect, would benefit from academic development initiatives where reflective practice is the core of the pedagogical activities and is a 'directed reflective process' (Kahn et al. 2006, 7).

One such initiative is called FLEX and has been offered to academics at Manchester Metropolitan University, U.K. (MMU, thereafter). This reflective account aims to tell the story of the designer of FLEX, and an academic from the same institution who engaged with the FLEX initiative. The initiative presented aims to bridge the gap between formal and informal, internal and external, open and practice-based professional development. It illustrates a specific case where these approaches have been brought together, are integrated into an academic programme at postgraduate level and harnessed by a specific academic. This paper aims to provide insight into the experiences of using FLEX from the student and tutor perspective and that will inform the evaluation and future enhancements of the initiative.

\section{What is FLEX?}

FLEX is practice-based professional development initiative for academic staff and other professionals who teach or support at MMU or externally (Manchester Metropolitan University, 2018). It is offered formally through a 15 and 30 credit postgraduate modules as part of the MA in Higher Education as well as informally for those who engage perhaps more pro-actively in professional development and feel that FLEX provides them with a useful framework for this. What is unique about FLEX, is that it harnesses formal, informal and open, as well as organised and practice-based or on-the-job professional development (some of these have been captured in Table 1 but this list is not exhaustive) driven by the individual, their professional needs and aspirations to enhance specific aspects of their teaching. The FLEX initiative has been openly licensed so that colleagues in other institutions can consider using and adapting it to their context and also consider collaborating with Manchester Met in this area.

What is different in FLEX is that it is fully a practitioner-driven module with interwoven capability to enable academics to gain academics credits at postgraduate level via reflecting critically on their practice and identifying opportunities for enhancement and making change happen. It is open by design and students are encouraged to engage and use formal, informal as well non-formal activities and reflect on these in their portfolio (see Table 1). Many of these harness a wide range of open offers. These include, among others, cross-institutional professional development initiatives such as the weekly Learning and Teaching in Higher Education tweetchat (\#LTHEchat); the monthly webinar series Teaching and Learning Conversations (TLC); the open community Creativity for Learning in Higher Education (\#creativeHE); the open courses such as the Bring Your Own Devices for Learning (BYOD4L); or the Learning and Teaching workshops offered by the MMU Centre for Excellence in Learning and Teaching and other MMU colleagues.

International Journal of Management and Applied Research, 2018, Vol. 5, No. 2 
Table 1: Indicative professional development activities used for FLEX

\begin{tabular}{|c|c|c|c|c|}
\hline $\begin{array}{l}\text { observation of } \\
\text { teaching/ } \\
\text { microteach } \\
\text { session }\end{array}$ & $\begin{array}{l}\text { presenting at a } \\
\text { L\&T } \\
\text { conference/ } \\
\text { event }\end{array}$ & $\begin{array}{l}\text { participating in a } \\
\text { webinar }\end{array}$ & $\begin{array}{l}\text { participating in } \\
\text { an open course }\end{array}$ & $\begin{array}{l}\text { carry out } \\
\text { evaluation of } \\
\text { teaching activity }\end{array}$ \\
\hline $\begin{array}{l}\text { participating in } \\
\text { an internal } \\
\text { workshop }\end{array}$ & $\begin{array}{l}\text { attending a } \\
\text { conference/ } \\
\text { event }\end{array}$ & $\begin{array}{l}\text { leading a } \\
\text { webinar }\end{array}$ & $\begin{array}{l}\text { leading an open } \\
\text { course }\end{array}$ & $\begin{array}{l}\text { co-facilitating an } \\
\text { open course }\end{array}$ \\
\hline $\begin{array}{l}\text { co-facilitating } \\
\text { workshop }\end{array}$ & $\begin{array}{l}\text { pedagogical } \\
\text { research }\end{array}$ & $\begin{array}{l}\text { participating in } \\
\text { an external } \\
\text { workshop }\end{array}$ & $\begin{array}{l}\text { using self-study } \\
\text { resources }\end{array}$ & networking \\
\hline mentoring & coaching & $\begin{array}{l}\text { creating } \\
\text { resources for } \\
\text { students }\end{array}$ & $\begin{array}{l}\text { professional } \\
\text { discussion with } \\
\text { colleagues }\end{array}$ & (funded) project \\
\hline $\begin{array}{l}\text { participating in a } \\
\text { project }\end{array}$ & $\begin{array}{l}\text { leading a } \\
\text { pedagogical } \\
\text { project }\end{array}$ & $\begin{array}{l}\text { participating in a } \\
\text { short course }\end{array}$ & $\begin{array}{l}\text { leading a short } \\
\text { course }\end{array}$ & $\begin{array}{l}\text { creating } \\
\text { resources for } \\
\text { staff } \\
\text { development }\end{array}$ \\
\hline $\begin{array}{l}\text { curriculum } \\
\text { development } \\
\text { activity }\end{array}$ & $\begin{array}{l}\text { curriculum } \\
\text { enhancement } \\
\text { activity }\end{array}$ & $\begin{array}{l}\text { reflection on } \\
\text { practice }\end{array}$ & team-teaching & $\begin{array}{l}\text { evaluating a } \\
\text { student survey }\end{array}$ \\
\hline $\begin{array}{l}\text { discipline } \\
\text { specific } \\
\text { pedagogic } \\
\text { activity }\end{array}$ & $\begin{array}{l}\text { generic } \\
\text { pedagogic } \\
\text { research }\end{array}$ & peer review & listening event & $\begin{array}{l}\text { creating/ } \\
\text { adapting open } \\
\text { educational } \\
\text { resources }\end{array}$ \\
\hline $\begin{array}{l}\text { reading a L\&T } \\
\text { article, } \\
\text { paper/book }\end{array}$ & $\begin{array}{l}\text { discussion with } \\
\text { a colleague } \\
\text { around L\&T }\end{array}$ & $\begin{array}{l}\text { external } \\
\text { examining }\end{array}$ & validation panel & $\begin{array}{l}\text { visit, trip, } \\
\text { exhibition }\end{array}$ \\
\hline
\end{tabular}

\section{Research settings}

This article is an individual and collective reflection and resembles a narrative inquiry in which experiences of two individuals (tutor and student) are captured and explored (Clandinin \& Connelly, 2000). The reflections shared are based on a webinar conversation whereby the authors embarked on a reflective dialogue in the content of a flexinar professional development series hosted by AdvanceHE (formerly Higher Education Academy). This gave the authors the opportunity to share their story and reflect critically on their practice from the perspective of the student and tutor linked to a specific academic development intervention. They decided to include some dialogic extracts from a conversation to bring some of the topics they explored alive.

Additionally, registration and completion data have been collected over the period of four years and represent completion rate of the FLEX initiative.

International Journal of Management and Applied Research, 2018, Vol. 5, No. 2 


\section{Results}

Since 2013/14, the year that it was launched, FLEX has grown significantly with successful completion steadily increasing from two in the academic year 2013/2014 to 43 in 2016/2017 (Figure 1).

Figure 1.The growth of the FLEX initiative (completion per academic year)

\section{Distribution of growth}

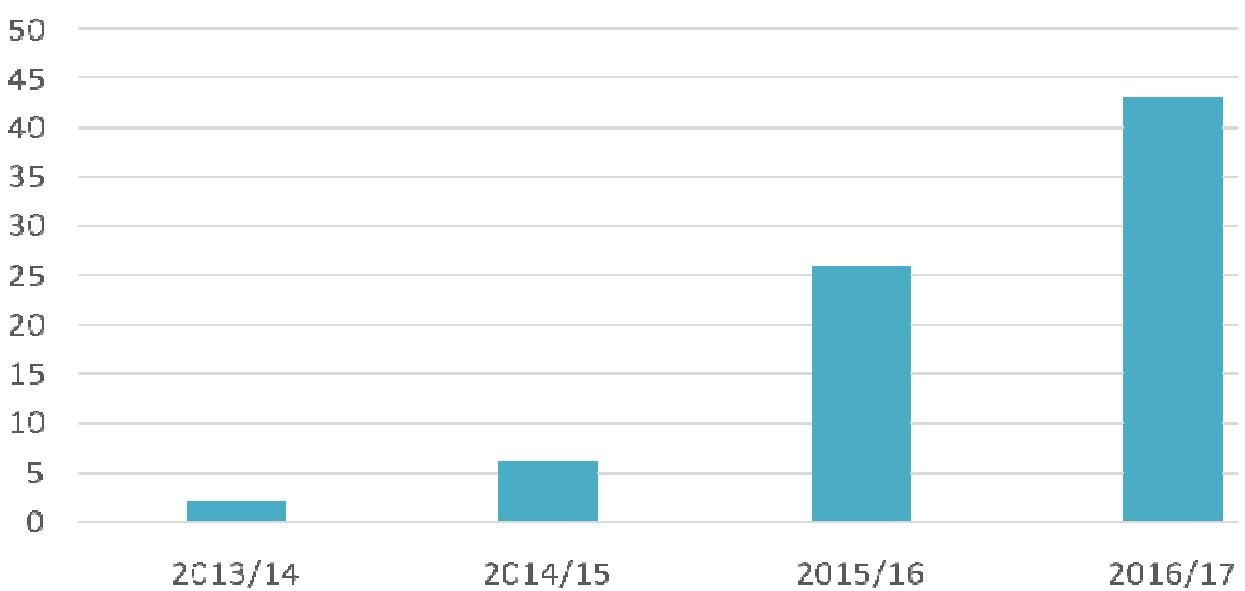

How motivation influenced their participation in FLEX is narrated by the tutor and student.

Student: How was FLEX developed?

Tutor: When I arrived at Manchester Met in October 2013, FLEX was a single module at Postgraduate level that had just been approved. I inherited it and was invited to create by vision for it. I found it useful to capture my ideas in a mind map. I was pleased that my ideas were supported and I started planning to bring FLEX to life.

Student: what is your aim through FLEX?

Tutor: The key idea behind FLEX for me became to find attractive and flexible ways, as the name suggests, to engage academics and further professionals who teach in our institution in professional development that was practitioner-driven and practice-based and help them develop as reflective practitioners committed to act on making informed changes to their practice.

Through FLEX, academic credits can be gained and used towards a PgCert in Learning and Teaching in Higher Education/Higher Education or the Masters in Higher Education. Furthermore, FLEX provides a route towards Fellowship by AdvanceHE and also enables individuals to engage informally with Continuous Professional Development.

International Journal of Management and Applied Research, 2018, Vol. 5, No. 2 


\section{Living FLEXIBLY with FLEX}

Tutor: What attracted you to FLEX?

Student: There were a number of factors that attracted me to FLEX. I am by nature and training a very reflective practitioner (both as an academic and clinician). I perceive reflection as my way of improving my practice and an avenue to professional and personal development. Hence, I was attracted to FLEX as this would give me a structure through which I would be able to reflect in a systematic way and with a specific aim. Further, familiar with the MMU strategic agenda, it was clear to me that by engaging with FLEX I would also align myself with the University objectives and standards for academic practice. Alongside these more theoretical in nature drivers, I was also looking for mechanisms to capture my development as an academic as I was chasing a promotion. Regardless, FLEX would also allow me to satisfy my curiosity by providing me with the opportunities to see what other colleagues do in their practice, but also my insecurities (am I good enough?). At a more practical level, and within a very stretched workload, engaging with academic development, which would require formal approvals by senior management, would ring-fence some time for me, which I believe that I owe to my students but also deserve it - almost like being between a rock and a hard place. The time allocated for my academic development is taken out of the time that should have been dedicated to my students - but the products of my development go back to them. Also, surely... one would say..., after so many years in learning and teaching in higher education don't I... and all... deserve a specific time and a safe place where the focus is me and how I can do things better, differently, perhaps in a way that is more fun for me? I believe I do and would encourage all to do so too.

Process: The professional development activities around learning and teaching are self-selected by the FLEX students based on personal priorities, needs and aspirations. These can include triggers relating to workshops or courses they participated or led internally or externally as well as conferences or events. They can also be of nonorganised nature such as a professional discussion with a colleague, an inspiration through reading an article or watching somebody in practice. The individuals are asked to critically reflect on these activities and link them to their practice. And through their reflection, they were expected to identify specific and informed ways to move their practice into new directions.

Assessment: The identified scholarly activities that FLEX students choose to reflect upon are captured in a digital portfolio. This portfolio is seen as potentially useful beyond the boundaries of FLEX; as a space for ongoing reflection on teaching practice. The digital academic portfolio can then be used for personal and professional development linked to institutional Professional Development Review processes, externally for specific professional bodies, and to establish an online presence. The portfolio is created using social media, and WordPress is suggested as a platform

International Journal of Management and Applied Research, 2018, Vol. 5, No. 2 
because it is an established and reliable platform as well as open access and user friendly. The portfolio is owned by the individual, something that has been highlighted as beneficial by Scully, O'Leary and Brown (2018). The portfolio is used during FLEX to capture the reflective process and assessment outputs relating directly to FLEX if undertaking for credits. An earlier pilot by Nerantzi and Botham (2016), relating to FLEX in use to evidence Continuous Professional Development, confirmed that the portfolio aids the development of reflective habits. Its digital dimensions were found to enable sharing and professional conversations to take place, while it was also acknowledged that the portfolio itself can present an adaptive challenge.

Tutor: how did you find the use of the digital portfolio?

Student: Nightmare... simply nightmare... at first, I had to choose specific activities that I would reflect upon. This is when FLEX became all too FLEXible for me. I felt lost! I vividly remember to challenge my original wish to engage with it all. And... as I often do in similar situations, I started to attribute my dissatisfaction to external causes. Suddenly, "The handbook is not effective...", and hence I had to spot the gap... find the mistake... be critical... all processes that I am professionally equipped to do... and have been applying for years in both my teaching and research. I had concluded that I did not enjoy my PgCert, and one of the reasons had to be the lecturer. So, I decided to actively pester her... challenge her and seek continuous... and in reflection... often unnecessary support.

It was this time, however, that a deep realisation occurred. It was a sort of a light bulb moment: "Hang on... is this how my students feel?" This question was the starting point of a transition, from a self-disenfranchised student to an active learner. I started to allow myself to immerse in the tasks needed and my reflections helped me navigate through FLEX. I also, very consciously, decided that I would share with my students the fact that I am also a student. This was part of my reflective plan. I had to use this experience within my teaching... this congruence was powerful. I was truly capable to share the similar anxieties my students had before a due date, their apprehension with something not as clear, their need... at least of some of them... to do well, their procrastination... for which I am also an expert!

And while I thought that I was on the right track with all of the above, I realised that I would be assessed via the infamous digital portfolio... or as I used to call it by paraphrasing J.K. Rowling "the Voldemort assignment" ... or the "It-WhichMust-Not-Be-Named". "I am an academic... not a blogger", I thought... the idea that I had to develop a blog battled with my skewed understanding of my professional identity. "I don't have time for this..." was what I would say in an attempt to justify my resistance. I wanted to dissociate from it... and, in reflection, my most desperate excuse was that "You cannot teach an old horse new tricks...". Hence, I needed support (again!)... and more support... and more... because MY portfolio HAD to be perfect (which, of course, fuelled my procrastination...).

However, the more I was getting into it, the more I started to enjoy it. This personal space, which was initially forcefully impressed upon me, became another safe

International Journal of Management and Applied Research, 2018, Vol. 5, No. 2 
place for me to reflect and develop. It was also fun... I could incorporate images, audios, texts, anything I wanted... it allowed me to be playful and creative. I was not restricted by APA or publishing guidelines. I was truly enjoying this, especially when I found out that I scored an $85 \%$, which was very rewarding... and certainly an internal attribution...

Feedback: Portfolio links are shared with the unit leader and the progress and the feedback is captured electronically. The unit leader does not police the engagement with FLEX. It is the individuals' responsibility to seek feedback on specific aspects of their work, in line with Boud and Molloy's (2013) generations of feedback and specifically what they refer to as Mark 2 that is driven by the learner. This approach has worked well and evidence gathered from 2013/14 to 2016/17 shows that overall $79 \%$ of individuals requested formative feedback on their work in progress at least once (see Figure 2).

Figure 2: Feedback on FLEX work in progress from 2013/14 to 2016/17

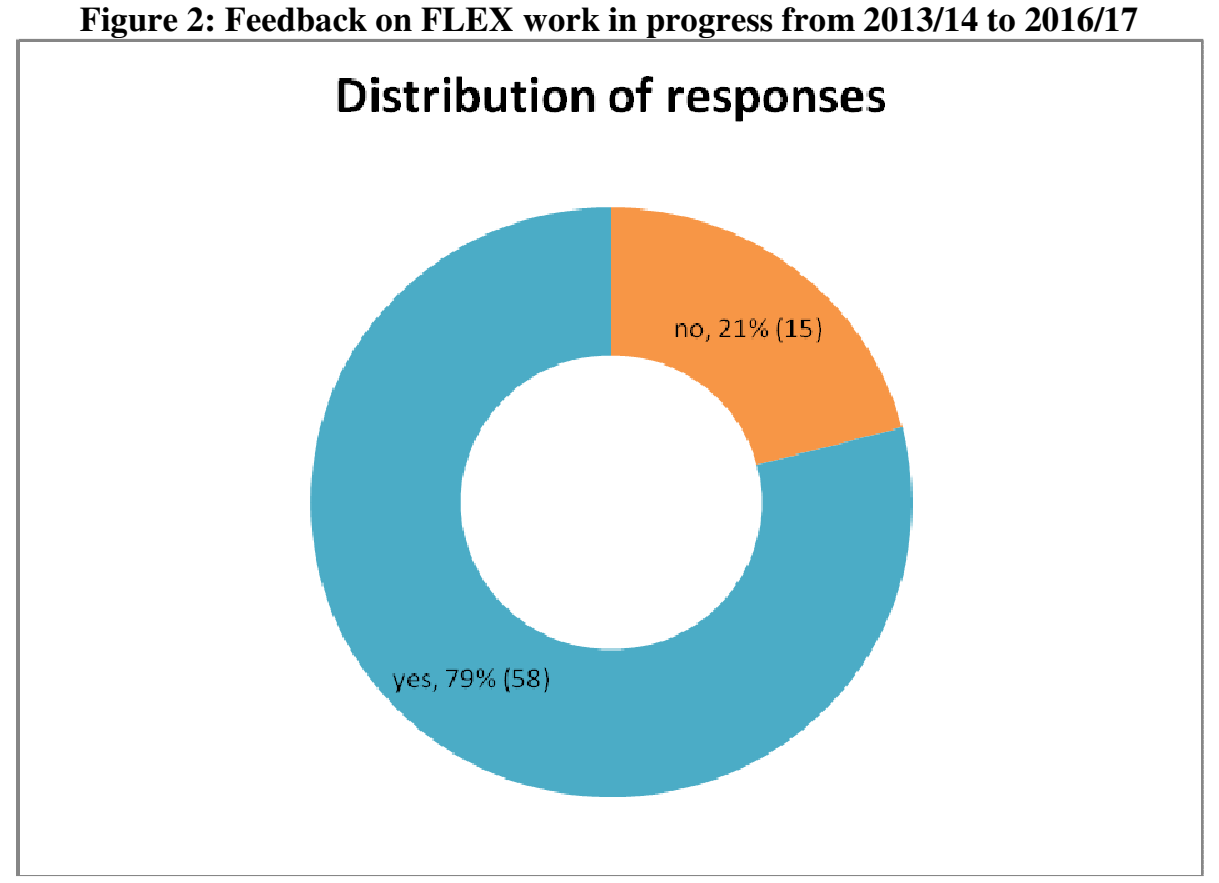

There is no limit to the number of feedback interactions individuals can request. However, as can be seen in Table 2, 49\% of individuals requested formative feedback on their work more than once.

Table 2: Feedback frequency 2013/14 to 2016/17

\begin{tabular}{lcccr}
\hline Asked for feedback & Average grade & No of Students $(\mathrm{n}=73)$ & $\%$ & Grade range \\
\hline $\mathbf{0}$ & 71 & 15 & $\mathbf{2 1 \%}$ & $52-82$ \\
$\mathbf{1}$ & 73 & 22 & $\mathbf{3 0 \%}$ & $62-82$ \\
$\mathbf{2}$ & 68 & 13 & $\mathbf{1 9 \%}$ & $50-82$ \\
$\mathbf{3}$ & 79 & 10 & $\mathbf{1 3 \%}$ & $68-85$ \\
$\mathbf{4 +}$ & 77 & 13 & $\mathbf{1 7 \%}$ & $68-98$ \\
\hline
\end{tabular}

International Journal of Management and Applied Research, 2018, Vol. 5, No. 2 
Table 2 also provides the scores that students achieved after they were moderated. However, in the absence of a baseline assessment of students' ability, no statistical analysis has been made to establish the effects of the frequency of feedback on students' mark, and the numbers of confounding variables do not allow a meaningful analysis to be completed.

Based on a visual inspection of the data, however, the frequency of feedback does not appear to increase students' academic performance, confirming previous literature that challenged the concept of 'more is better' (Lam et al. 2011). Establishing such a relationship statistically would be beneficial for programme planning. The generation of data based on baseline measures assessing students' ability at the start of their FLEX journey should be collected in the future. Regardless, as feedback is provided upon request and individuals do have one calendar year from registration to complete the FLEX unit, the demand for the unit leader to provide the feedback is spread accordingly. This enables the unit leader to engage with individual work more effectively and creates opportunities for asynchronous feedback conversations through the portfolio space, therefore closing the feedback loop before submission. As the majority of individuals request formative feedback, the final submission is therefore familiar to the unit tutor and, in effect, marking is less time consuming. In addition, the summative feedback stretches the individual beyond what has been achieved to what could be achieved in the future.

\section{Discussion}

This paper aimed to present a narrative reflective account between an academic developer and an academic attending FLEX, a CPD unit offered at MMU. The narrative aimed to capture both the structure of the Unit but also the collective experience and new understandings of the provider and the consumer. Overall, FLEX seemed to be experienced positively by both partners. Before such a conclusion can be reached, however, some limitations need to be considered.

This reflective narrative is based on a single case, which by default would not represent a collective sense making of the student body. It is possible that other students had a completely different experience. It would therefore be useful to contact further research into the collective experience of FLEX to gain further insights and to identify the variations of the experience. Such an exploration would not necessarily be useful to each individual that has completed FLEX or those considering enrolling in FLEX, but it would inform future enhancement of the FLEX initiative and the staff experience engaging with this. A different potential limitation relates to the fact that the student involved is highly experienced with reflective practice due to his academic specialisation. It is possible that this enabled the student to embark on the FLEX journey equipped with the skills to reflect upon his practice to a more advanced level that someone whose specialisation does not ordinarily require reflexivity. However, FLEX is structured around a 'directed reflective process' (Kahn et al. 2006, 7) and the nature of support is based on an organically developed dialogue both at intra-personal level (i.e. between the student and their reflections) and at inter-personal level (i.e. between the student and the unit lead via discussions and formative feedback). Hence, while past reflective practice might help the student identify their own emotions and

International Journal of Management and Applied Research, 2018, Vol. 5, No. 2 
responses to them to a certain degree, our data do not suggest that this gives any significant advantage towards successful completion. Conversely, FLEX might be beneficial for academics who are new to reflection as it provides a scaffold to develop reflective skills and reflective habits.

Regardless, the students' ability at entry stage to FLEX is a key in allowing the implementation of more sophisticated analysis around the impact of the frequency of feedback provision. As feedback is looked at from an academic experience perspective and metrics are indeed gathered on its quality, establishing the optimum frequency of feedback could potentially shed further light on the topic and help developers design programmes that are based on evidence.

\section{Recommendations}

\section{FLEX credits and duration}

Currently, FLEX is offered as a 15 and 30-credit module, which is administratively demanding. An alternative approach that would simplify the academic administration would be to just offer the 15-credit module. Interested colleagues could then register in an additional 15-credit FLEX module, if they so wished.

FLEX currently runs across twelve months. Shortening the module duration to one term in combination with making the module available as a 15-credit repeat module, could help the process of staying focused and making progress with FLEX quicker. The flexibility and duration often result in lower levels of engagement from the start, with valuable time potentially being lost. Reducing the overall module duration may limit this.

\section{FLEX feedback}

As many portfolios remain private, feedback is provided mainly by the module leader. There is also, however, an opportunity to establish a mechanism for peer-feedback (Bernstein,Burnett, Goodburn \& Savory, 2006). In fact, Boud and Walker (1998) emphasised the benefits of sharing reflections in professional courses. FLEX students, therefore, could be alerted to the benefits of sharing reflections with other FLEX students and the wider academic community and encouraged to do so too. This could be achieved by perhaps modelling this practice more explicitly. While peer feedback could take place at any time throughout the course, the most suitable time for making the portfolios public might perhaps be after the summative assessment is provided. This would address the added pressure by the fact that for those seeking academic credits FLEX outputs are assessed.

\section{FLEX assessment}

Having offered FLEX for 4 years, there are now plans to review the assessment strategy and identify ways to add further flexibility in this regard. For example, currently students are asked to capture three FLEX activities for the 15-credit module and five activities for the 30-credit module. The decision to reflect upon five activities for the 30-credit module was based on the five areas of activities of the UK

International Journal of Management and Applied Research, 2018, Vol. 5, No. 2 
Professional Standards Framework (HEA, 2011). While a specific number of activities seems to be helpful for colleagues, there is a possibility for further flexibility. For instance, students could reflect on a smaller number of activities overall, or a series of activities that are more closely related and could be articulated even as one ongoing reflective narrative (that meets a standard word count) without breaking it up into smaller chunks.

\section{FLEX research}

Although the reflective nature of FLEX encourages students to assess their practice and identify ways to improve it, a more structured self-evaluation that students engage with at the beginning (as a baseline) and at the end or even a year after completion would enable the generation of valuable data that capture the student journey. Such data can be used in the context of research, service evaluation, service development and for capturing student satisfaction. Importantly, such data could be shared with the FLEX students as a mechanism of further feedback that captures their progress.

\section{FLEX across institutions}

Colleagues from other institutions have shown interest in FLEX, but to our knowledge FLEX has not been adopted elsewhere yet. It would be possible to seek at least one institution that would be willing to collaborate and connect colleagues from both institution for peer dialogue and shared reflection on their work.

\section{FLEX as an option for postgraduate taught provision}

The structure of FLEX lends itself to PG courses that require reflexivity. Hence, a 15 credit unit taught within one term could be incorporated into the curriculum of courses such as Psychology. This would be particularly relevant for competencies and employability/professional skills development, training reflective practitioners and for lifelong learning. There is also scope for FLEX to be used as a CPD professional development course that offers professional body accreditation units. This would require collaboration with professional bodies that offer such opportunities (e.g. British Psychological Society, the General Medical Council).

\section{Conclusion}

Tutor: what did you get out of FLEX?

Student: FLEX was a great experience. Practically, all of my needs were met. I received my PgCert and became a Fellow of the Higher Education Academy (I am currently exploring the Senior Fellowship). I also captured my skills development and indeed got promoted to Senior Lecturer. However, the most important benefit from FLEX is that in line with a piece of advice in the content of one of the sessions... 'I dare'... I dare to challenge my students differently and more effectively to what I used to do before. I dare to speak with my students about topics that I would self-censor before; topics that are relevant to current affairs and by approaching them through a psychologically informed way I believe that it enables them to develop their civic skills and also apply theory to practice. I dare

International Journal of Management and Applied Research, 2018, Vol. 5, No. 2 
to use creative approaches that I would not even contemplate in using (e.g. tennis balls to encourage participation, or coffee jars to receive feedback). I dare to have fun. This has resulted in me enjoying my sessions more than I used to before, whether these are teaching large undergraduate groups, small more intimate postgraduate student groups, or supervisions. And from a recent nomination for the 'Best Supervisor Award' for 2018, I guess that my students seem to enjoy it too.

\section{Student: What would your take-home message be?}

Tutor: As you say, "I dared", we, academic developers also need to dare. Dare to be different, dare to do the unusual, dare to sail outside the port... and take risks, but also dare to let go of control, to trust, to create a sense of freedom and empowerment.

Based on the analysis and the reflections presented, the authors explored specific aspects of the FLEX experience from the student and staff perspective and its potential value for academic staff development. This single case evidences that the FLEX initiative has the potential to provide a plethora of benefits to academics and their professional development that are career enhancing and have an impact on their own teaching practice and the student experience. Such practices also create opportunities for collaborations between academics and academic developers that foster impact and growth that extends beyond the boundaries of a module. HE is a social act, and hence attempting to generate new understandings through an interdisciplinary and shared reflective narrative that is routed in social constructivism seems to be an appropriate way forward for identifying and acknowledging our personal and collective boundaries and also the opportunities for development and change. Stefani (2017) notes that academic development should be transformative: transformative in its offer, transformative in its impact. FLEX appears to create such opportunities among academic staff who engage with this initiative as this reflective narrative indicates. However, it needs to be acknowledged that in this article, a single case is presented and therefore the findings relate to this. Further and more systematic research in this area is required to identify the wider implications of FLEX on practice linked to the wider population of FLEX.

\section{Acknowledgements}

We would like to thank Dr Alex Avramenko for encouraging us to write this article and our first critical reader Margy Macmillan for her valuable suggestions on the first draft as well as the reviewers of the journal for helping us improve this article further.

\section{References}

1. Baume, C. and Baume D. (2013), "The birth and death of academic development? Innovations in education and teaching international", Innovations in Education and Teaching International, Vol. 50, No. 4, pp. 384-387.

https://doi.org/10.1080/14703297.2013.839391

International Journal of Management and Applied Research, 2018, Vol. 5, No. 2 
2. Bernstein, D., Burnett, A. N., Goodburn, A., and Savory, P. (2006), Making teaching and learning visible: Course portfolios and the peer review of teaching. Bolton, MA: Anker.

3. Botham, K. A. (2017), "The perceived impact on academics' teaching practice of engaging with a higher education institution's CPD scheme", Innovations in Education and Teaching International, Vol. 55, No. 2, pp. 164-175. https://doi.org/10.1080/14703297.2017.1371056

4. Boud, D. and Molloy, E. (2013), "Rethinking models of feedback for learning: the challenge of design", Assessment \& Evaluation in Higher Education, Vol. 38, No. 6, pp. 698-712. https://doi.org/10.1080/02602938.2012.691462

5. Boud, D. and Walker, D. (1998), "Promoting reflection in professional courses: The challenge of context", Studies in Higher Education, Vol. 23, No. 2, pp. 191206. https://doi.org/10.1080/03075079812331380384

6. Camargo-Borges, C. and Rasera, E. F. (2013), "Social Constructionism in the Context of Organization Development: Dialogue, Imagination, and Co-Creation as Resources of Change", SAGE Open, https://doi.org/10.1177/2158244013487540

7. Chatzidamianos, G. (2017), "Teaching Ethics in HE: the why's and the how's", presented at the 1st International Conference Educational Leadership, Effective Administration and Ethical Values, 24-26 November 2017, Thessaloniki, Greece.

8. Chatzidamianos, G. (forthcoming), "Teaching Ethics in a Social Age: the use of ICT in Educational Leadership", In V. Karavakou (Ed), Reclaiming Educational Leadership: Responses to modern problems and challenges, Greece: Springer.

9. Clandinin, D. J. (2006), "Narrative Inquiry: A Methodology for Studying Lived Experience", Research Studies in Music Education, Vol. 27, No. 1, pp. 44 - 54. https://doi.org/10.1177/1321103X060270010301

10. Clandinin, D. J. and Connelly F.M. (2000), Narrative Inquiry: Experience and Story in Qualitative Research, San Francisco: Jossey-Bass Publishers.

11. Crawford, K. (2009), Continuing professional development in higher education: Voices from below, EdD thesis, UK: University of Lincoln. Available from: http://eprints.lincoln.ac.uk/2146/1/Crawford-Ed\%28D\%29Thesis-CPDinHEFINAL\%28Sept09\%29.pdf [accessed on 4 July 2018].

12. Gibbs, G. (2013), "Reflections on the changing nature of educational development", International journal for academic development, Vol. 18, No. 1, pp. 4-14. https://doi.org/10.1080/1360144X.2013.751691

13. Higher Education Academy (HEA) (2011) The UK Professional Standards Framework for teaching and supporting learning in higher education. Information Note. York: Higher Education Academy. Available from: https://www.heacademy.ac.uk/ukpsf [accessed on 4 July 2018].

14. Kahn, P. Young, R. Grace, S., Pilkington, R. Rush, L. and Willis, I. (2006), The role and effectiveness of reflective practices in programmes for new academic staff: a grounded practitioner review of the research literature, York: Higher Education Academy, available from: https://www.heacademy.ac.uk/system/files/reflective_practice_full_report.pdf

International Journal of Management and Applied Research, 2018, Vol. 5, No. 2 
[accessed on 4 July 2018].

15. Lam, C.F., DeRue, D. S., Karam, E. P. and Hollenbeck, J. R.(2011), “The impact of feedback frequency on learning and task performance: Challenging the "more is better" assumption", Organizational Behavior and Human Decision Processes, Vol. 116, No. 2, pp. 217-228. https://doi.org/10.1016/j.obhdp.2011.05.002

16. Manchester Metropolitan University (2018), FLEX: practice-based CPD, [Online] available from: http://www.celt.mmu.ac.uk/flex/index.php [accessed on 4 July 2018].

17. Nerantzi, C. (2017), Towards a cross-boundary collaborative open learning framework for cross-institutional academic development, $\mathrm{PhD}$ thesis, $\mathrm{UK}$ : Edinburgh Napier University.

18. Nerantzi, C. and Botham, K. (2016), "FLEX to evidence Good Standing", Learning and Teaching in Action Journal, Vol. 11, No. 2, pp. 57-69, available from: http://www.celt.mmu.ac.uk/ltia/Vol11Iss2/LTiA_Volume11_issue2.pdf [accessed on 4 July 2018].

19. Parsons, D., Hill, I., Holland J. \& Willis, D. (2012) Impact of teaching development programmes in higher education. York: The Higher Education Academy. Available from:

https://www.heacademy.ac.uk/system/files/resources/hea_impact_teaching_develo pment_prog.pdf [accessed on 18th October 2013].

20. Phuong, T. T., Cole, S. C. and Zarestky, J. (2018), “A systematic literature review of faculty development for teacher educators", Higher Education Research \& Development, Vol. 37, No. 2, pp. 373-389. https://doi.org/10.1080/07294360.2017.1351423

21. Robbins Report (1963), Higher education report of the committee appointed by the Prime Minister under the chairmanship of Lord Robbins, committee of higher education. Available from:

http://www.educationengland.org.uk/documents/robbins/robbins1963.html [accessed on 3 May 2018].

22. Schön, D. (1983), The Reflective Practitioner: How professionals think in action. London: Temple Smith.

23. Scully, D., O'Leary, M. and Brown, M. (2018), The Learning Portfolio in Higher Education: A Game of Snakes and Ladders. Dublin: Dublin City University [Online], available from: http://dcu.ie/sites/default/files/carpe/eportfolio_report.pdf [accessed on 3 May 2018].

24. Stefani, L. (2017), "Realizing the potential for creativity in teaching and learning", in: Blessinger, P. and Watts, L. S. (eds.), Creative Learning in higher education: International perspectives and approaches, London: Routledge, pp. 196-209.

25. Sutherland, K.A. (2013), "The importance of critical reflection in and on academic development", International Journal for Academic Development, Vol. 18, No. 2, pp. 111-113. https://doi.org/10.1080/1360144X.2013.802074

International Journal of Management and Applied Research, 2018, Vol. 5, No. 2 